\title{
External Influences on Domestic Reforms in Post-Communist European Countries
}

Joan DeBardeleben and Lyubov Zhyznomirska 
Three articles in this special issue of the Review of European and Russian Affairs address the complex interaction of domestic politics and international influence as a source of the reform processes in Eastern European countries. Patricia Young and Nikolas Rajkovic critically assess the literature on conditionality and compliance politics based on the case studies of Romania and Serbia respectively. In turn, Frederick Peters interrogates how ideological shifts in the modes of capitalist accumulation at the global level change the balance between the private and public at the local level of supply of social needs in post-communist countries of Estonia and Russia. What the authors convincingly show is that political and economic processes at the domestic and international levels do not exist in isolation from each other but are closely interlinked and interdependent. As international organizations, be it the European Union or international financial institutions (IFIs), and the conditionality they impose affect the reform processes in a particular country or region, the analysis of the effectiveness of their conditionalities and what reforms and processes they evoke at the national/local levels needs to be sensitive to the domestic context of compliance politics. It should also reveal the interests served and ideologies supported in promoting a particular type of political/economic/social change at the local level.

While the European Union may be effective in evoking political and economic reforms by imposing conditionality clauses during the accession negotiations, the analysis of the effectiveness of this conditionality requires more than just the analysis of whether the EU has succeeded in extracting compliance. In Democratic and Market Governance in Romania: Between Domestic Politics and EU Accession, Patricia Young evaluates the quality of institutions created as the result of the political and economic reforms in Romania (required by the EU accession negotiations in 2000-2004 and pre-accession monitoring in 2004-2006) in order to assess the effectiveness of EU conditionality to institutionalize and deepen new 
democratic governance rules in Eastern Europe. Young argues that real reforms in political and economic governance cannot be undertaken only by adopting the 'right' laws based on European values and principles. She suggests differentiating between the passage of legislation and its consequent implementation, and giving more attention to the effects of the lack of political will to implement the adopted reforms.

Young also compares EU conditionality in the realms of political and market governance reforms and concludes that economic reforms required by the European Commission as part of accession conditionality "do not appear to have suffered from the same political interference as the political governance reforms." Nevertheless, Young notes the existing disconnect between economic laws on the books and in practice and observes that market governance efficiency continues to be impaired by corruption and a politically dependent judiciary. As a result, despite the successes of the EU in promoting economic and political reforms in Romania during accession negotiations, Young convincingly argues that the effectiveness of the legislated reforms is yet to be proven.

In The Limits of Consequentialism: ICTY Conditionality and (Non)Compliance in PostMilosevic Serbia, Nikolas Milan Rajkovic challenges the capacity of a rational-consequentialist approach, dominant in the literature on compliance politics, to account for the changing pattern of compliance and non-compliance with the International Criminal Tribunal on the Former Yugoslavia (ICTY) conditionality by Serbian governments since the year 2000. Rajkovic suggests that the explanatory power of a rational-consequentialist model is limited because it gives priority to material incentives but downplays the importance of normative and temporal aspects of conditionality and compliance process. He suggests that the quality of prescribed norms and rules that "attempt far-reaching institutional and social change" can trigger 
multidimensional and politically complex historical processes, and these processes cannot be accounted for by the rationalist model. Instead, Rajkovic calls for "a more contextual way of studying compliance politics" that would allow to uncover "the unique material, normative and temporal dimensions of compliance politics and practice."

To demonstrate the limits of the rationalist model and sketch some alternatives, Rajkovic utilizes inductive process-tracing to study ICTY compliance during the Kostunica government in Serbia in 2004-2007. He focuses on such dimensions as (1) strategic calculation; (2) identity and cultural tolerance; and (3) temporality; Rajkovic emphasizes the importance of studying and theorizing context "as a field of practice with variable realizations and meanings across time." By investigating the Kostunica government's (non)compliance with the ICTY conditionality, the author attempts to show how multi-dimensional and diachronical the practice of compliance politics is, and how certain incentives, identity frames or events get their significance under a particular historical sequence of events. Rajkovic concludes that 'thick descriptions', sensitive to both material and normative and temporal aspects, reveal the complexity of compliance politics experience and are more representative of political 'reality' than a rationalist and model-driven outlook can suggest.

Finally, in Accumulation by Any Means: Neoliberalisation and Environment in PostCommunist Europe, Peters traces the interconnections between macro level changes in the global economy and shifts in the local practices of supplying human basic needs in an urban context. He explores water services restructuring in post-communist Europe by utilizing the case studies of two cities, St Petersburg in Russia and Tallinn in Estonia. While major attention in the literature has been given to the role and involvement of the World Bank (WB) and the International Monetary Fund (IMF) in promoting restructuring and transition to market in the 
post-communist countries, the role of the European Bank of Reconstruction and Development (EBRD), the European Union's institution established to rebuild environment and infrastructure in the post-communist world, has not received equal attention. Hence Peters analyzes the EBRD's involvement in specific local projects of water supply restructuring and strategic partnerships formed in the Baltic region in order to shed some light on the development of its capacity and strategy as an investor in the infrastructure in the region since the early 1990s. Peters argues that an analysis of ownership restructuring and the conditions of investments in the urban centres of the Baltic region challenges the notion that market reforms lead to democratic institution-building; rather, his study reveals a deficit of democratic control over restructuring and privatization processes. On the basis of his case studies, Peters concludes that privatization of water supply infrastructure in the region shows "ideological shifts in the balance of public versus private management and opportunism using public money to support capitalist intensification at the expense of public benefit." He suggests that in order to understand transformation in governance practices and relationship of the state to market in the management of environment and infrastructure, markets and political institutions should be treated as interrelated and constitutive of each other, with state institutions being implicated in the constitution of both national and international economic structures. In addition, Peters suggests that political scientists should pay more attention to how management paradigms from the corporate sector have transformed governance thinking, both at the national and international levels.

While all of these articles examine post-communist transformation, they relate to countries at varying 'distances' from the EU-Europe. Conventional wisdom would suggest that the further ones moves outward through the concentric circles of prospective EU membership, 
the lesser would be an impact of European values, Europeanization or conditionality based on Western values and practices. The three articles in this volume provide a perspective from which to view this proposition. While Young's article deals with a very new EU member (Romania), Rajkovic's study deals with an ambivalent EU-aspirant (Serbia), which has been explicitly identified by the EU as a prospective future member. Frederick Peters' two cases include one relatively new EU member state (Estonia) and one EU 'non-aspirant' (Russia). In each case, the authors show both the capacity and weaknesses of international institutions, including but not limited to the EU, to motivate or fail to motivate domestic political action. What becomes strikingly clear from the three articles is that the strength of international influence is variable and is not necessarily correlated with a country's EU aspirations. Equally evident is the difficulty of translating specific policies demands into the normative outcomes that the EU and other Western actors promote (such as democratic governance, principles of justice, or fair market competition). In each case there are intended as well as unintended consequences of attempted international influence on domestic politics, which are strongly influenced by the specific historical trajectories of the particular nations involved. 